\title{
Adaptive Responses to Climate Change: The Effects of Temperature Levels on Residential Electricity use in China
}

\section{Meixuan Teng}

Beijing Institute of Technology

Hua Liao ( $\square$ hliao@bit.edu.cn )

Beijing Institute of Technology https://orcid.org/0000-0002-4835-927X

Paul J. Burke

Australian National University

Tianqi Chen

Beijing Institute of Technology

Chen Zhang

Chengdu Library and Information Center Chinese Academy of Science

\section{Research Article}

Keywords: adaptation, China, climate change, electricity consumption, residential.

Posted Date: September 1st, 2021

DOI: https://doi.org/10.21203/rs.3.rs-852560/v1

License: (9) This work is licensed under a Creative Commons Attribution 4.0 International License. Read Full License 


\section{Adaptive responses to climate change: The effects of temperature 535 levels on residential electricity use in China}

537 Abstract: Rising temperatures are likely to boost residential demand for electricity in warm locations

538 due to increased use of air-conditioners, fans, and refrigeration. Yet the precise effect of temperatures

539 on residential electricity use may vary by geographical area and with socio-economic conditions.

540 Knowledge on this effect in developing countries is limited due to data availability and reliability issues.

541 Using a high-quality provincial-level monthly dataset for China and fixed-effect panel methods, we find

542 a U-shaped and asymmetrical relationship between ambient temperature and monthly household

543 electricity use. An additional day with a maximum temperature exceeding $34^{\circ} \mathrm{C}$ on average results in a

$5441.6 \%$ increase in monthly per capita household electricity use relative to if that day's maximum

545 temperature had been in the $22-26^{\circ} \mathrm{C}$ range. The effect of an additional cold day is smaller. There are

546 differences in effects for the south and the north of China and in urban versus rural areas. We estimate

547 that temperature increases associated with climate change will lead to about a 3-5\% increase in annual

548 household electricity consumption by the end of the century under different carbon emission trajectories

549 according to the projections in the 2021 IPCC report. The estimated effect is larger for summer months.

551 Key words: adaptation; China; climate change; electricity consumption; residential 
553 Adaptive capacity to climate change and to extreme temperatures is known to vary as a result of

554 differences in incomes and other underlying variables (Yohe and Tol, 2002; Ghimire et al. 2010; IPCC,

555 2014). However, specific adaptive responses among developing countries are less well understood than

556 those among developed countries (Dell et al. 2014; Revesz et al., 2014; Burke et al. 2016). China, the

557 largest developing country and world's most populous country, has suffered a faster temperature rise

558 than the global average level, at an average rate of $0.26^{\circ} \mathrm{C}$ per decade over $1951-2020$ (CMA, 2021).

559 This paper focuses on the response of residential electricity use to temperatures in China.

560 A key likely adaptation strategy to higher temperatures is increased used of electricity for air-

561 conditioning, fans, and refrigeration (Barreca et al. 2016; Park et al. 2020). In addition, people are often

562 more likely to stay at home on days of extreme heat. Household electricity consumption is likely to be

563 affected by temperature increases along both an intensive margin (residents tend to consume more

564 electricity from existing appliances) and an extensive margin (residents tend to purchase additional

565 household appliances such as air conditioners and fans). Many residents in developing countries such

566 as China are yet to install air-conditioning but are likely to do so over coming years (Wolfram et al.

567 2012).

568 The response of household electricity consumption to temperature may well vary across China given

569 the country's large latitudinal span and its urban-rural dualism. Differences in climate and in residential

570 energy use across China are large. Residents in both the north and south are inclined to rely on electricity 
571 for cooling in summer, using either electric fans or air conditioners. However winter fuels vary. Since

572 the 1950s, coal has been widely used for centralized heating in urban areas north of the Qinling-Huaihe

573 Line (Ebenstein et al. 2017). In recent times, some cities such as Beijing have used an increasing amount

574 of natural gas for heating. In the south, heating is primarily powered by electricity and there is little

575 centralized heating. Rural residents throughout the country are typically not connected to centralized

576 heating, instead relying on the combustion of biomass and scattered coal plus some use of electric

577 heaters.

578 Electricity consumption in China's household sector has increased thirtyfold since 1990. As of 2017,

579 the residential sector accounted for 14\% of China's total final electricity consumption (NBS 2019a).

580 The number of residential air conditioners in urban areas of China far exceeds that in rural areas, with

581 more than 200 air-conditioning units per 100 households in some urban areas often less than 100 units

582 in rural areas (NBS 2019b).

583 There is a body of research focusing on factors that influence electricity consumption such as electricity

584 prices, incomes, population, gender, urbanization level, and air pollution levels (Zhou and Teng 2013;

585 Al-Bajjalia and Shamayleh 2018; Tjørring et al. 2018; Eom et al. 2020). Many papers have examined

586 how electricity use responds to the number of cooling degree days (CDD) and heating degree days

587 (HDD) (Warren and Leduc 1981; Lam 1998). Prior studies vary between using time-series, cross-

588 sectional, or panel data (Franco and Sanstad 2008; Auffhammer and Aroonruengsawat 2011).

589 Most prior research has focused on developed countries, and especially the United States (Vine 2012; 

and for water pumping in California. They found that a scenario in which the average temperature

593 increases by $1.9^{\circ} \mathrm{C}$ would lead to an increase in electricity use of about $2.6 \%$. McCulloch and Ignatieva

594 (2020) used high-frequency electricity consumption data from Australia, finding a strong and time-

595 dependent relationship between electricity use and temperature. Mansur et al. (2008) estimated the

596 relationship between temperatures and fuel choices in the household and business sectors of the US,

597 finding higher demand for electricity and less demand for other fuels in warmer areas.

598 Among studies of developing countries, Zhang et al. (2019) used annual electricity consumption data at

599 the county level in rural areas in China, finding a difference in the responsiveness of rural electricity

600 consumption to high and to low temperatures. Berkouwer (2020) used micro data from South Africa to

601 explore the relationship between temperatures and household electricity consumption, concluding that

602 residential electricity consumption is likely to decrease by $6.2 \%$ per household relative to the 603 counterfactual if there is a $3.25^{\circ} \mathrm{C}$ increase in temperature by mid-century. This is largely due to reduced 604 heating needs in winter.

605 Most studies for China have examined the response of electricity to temperature at a fairly aggregated

606 level. Fan et al. (2015) and Asadoorian et al. (2008) used data by sector and region. There is a notable

607 gap in terms of research on rural areas. Evidence using household data is also rare due to data constraints.

608 One exception is the study of Li et al. (2019), who used daily household electricity consumption data 
609 for Shanghai over 2014-2016. They observed a U-shaped temperature-electricity response curve.

610 In this paper we explore the relationship between monthly residential electricity consumption and

611 temperature at the provincial level in China, conducting various heterogeneity analyses. The use of

612 relatively high frequency and geographically-disaggregated data is more suitable for identifying

613 temperature response functions than more aggregated approaches such as using national and/or annual

614 data. ${ }^{1}$ We also use the results to understand the likely effects of different climate scenarios on residential

615 electricity use in China by 2100 . Residential electricity consumption is particularly relevant for human

616 welfare and may be more sensitive to temperature than the electricity use of other sectors such as heavy

617 industry given the importance of temperature control at the residential level.

6182 Data and method

$619 \quad 2.1$ Data

620 Accurate provincial temperature data are needed for the study. Station-averaged or area-weighted

621 temperature data would not be ideal, as it is the temperatures where people live that should matter for

622 residential electricity use. Some provinces are geographically large and have clustered populations. We

623 thus use population-weighted temperature data.

624 Daily temperature variables were constructed as follows. First, we obtained daily maximum and daily

625 average temperature from the National Meteorological Information Center (NMIC) for around 700

626 weather stations. The data are believed to be highly accurate, with quality tests having been undertaken

\footnotetext{
${ }^{1}$ Monthly data are the most time-granular data on residential electricity consumption available for our sample.
} 
627 by the NMIC. County-level daily maximum and daily average temperatures were then calculated using

628 an inverse distance weighting procedure (Chen et al. 2017). This was done using average data from

629 weather stations located within $200 \mathrm{~km}$ of each county's centroid. We then constructed provincial

630 variables by weighting the county data by each county's population in China's 2010 census. Provincial-

631 level measures of relative humidity were calculated in the same way.

632 The empirical estimations will use "temperature bin" variables so as to focus on the effects of daily

633 weather fluctuations in a monthly specification. The approach also allows for potential non-linearity in

634 the effect of daily temperatures on monthly electricity use (Bessec and Fouquau 2008). First, all months

635 were normalized to 30 days. The daily maximum temperature data were then divided into ten bins,

636 ranging from below $2{ }^{\circ} \mathrm{C}$ to above $34^{\circ} \mathrm{C}$. We then calculated the number of days in each temperature bin

637 in each province in each month. The dataset covers 2008-2017 and 30 provinces. The weather data were

638 processed using ArcGIS and Python.

639 Figure 1 plots the distribution of the daily-maximum temperature bins, with each column showing the

640 average number of daily maximum temperatures in a bin for the dataset in 2017 . While extreme hot and

641 cold weather is somewhat rare, some regions face relatively high exposures. We use $22-26^{\circ} \mathrm{C}$ as the

642 baseline temperature bin in the estimations.

\section{Insert Fig. 1}

644 Figures 2 shows the average daily maximum temperatures in January and July of 2017 by province.

645 There is a huge gap in January maximum temperatures between the north and the south: the average 
646 daily maximum temperature is below $0^{\circ} \mathrm{C}$ in the northeast and northwest and above $20^{\circ} \mathrm{C}$ in some

647 provinces in the south. Southern provinces thus have much smaller heating requirements. In contrast,

648 there are relatively minor differences in the July average daily maximum temperature across China. This

649 temperature is below $30^{\circ} \mathrm{C}$ in most northern provinces and above $32^{\circ} \mathrm{C}$ in some southern provinces.

650

Insert Fig. 2

651 For residential electricity use, we use aggregate monthly data at the provincial level from the China

652 Electricity Council (CEC) and also provincial Bureaus of Statistics. Data were collected for 2008-2017.

653 Data are also available in a disaggregated form for both the urban and rural areas of each province for

654 the sub-period 2012-2017. Prior to 2006, China faced quite serious electricity shortages (NEA 2007).

655 Our sample period focuses on the more recent period of China's development history.

656 Figure 3 shows monthly per capita household electricity consumption in both summer and winter of

657 2017, as well as the number of air conditioners per 100 households in the residential sector. In most

658 provinces, per capita household electricity consumption is slightly higher in summer than winter, likely

659 due to use of air conditioners and electric fans. Electricity consumption in advanced provinces such as

660 Beijing exceeds that in the northwest, consistent with variation in the number of air conditioners. The

661 number of air conditioners in some southeast coastal provinces is above 130 per 100 households. This

662 number is below 10 in some northeast and northwest provinces.

Insert Fig. 3 
664 We obtained data on average annual per capita household incomes and the annual urbanization rate from

665 the China Statistical Yearbooks. The available statistics switch from per capita rural net income to per

666 capita rural disposable income as of 2013. We used a fixed rate of change method to unify the two series

667 into a single annual per capita disposable income measure. ${ }^{2}$

$668 \quad 2.2$ Method

669 The basic regression model is shown in equation (1):

$670 \quad \ln E C_{i, y, m}=\sum_{j} \alpha_{j} T E M P_{i, y, m, j}+\beta \ln Y_{i, y}+\lambda \vec{X}_{i, y}^{\prime}+\gamma_{i}+\omega_{y}+\varphi_{m}+\epsilon_{i, y, m}$

$671 E C_{i, y, m}$ is monthly per capita household electricity consumption divided by the number of days per

672 month (in consideration of month-to-month differences in the number of days). $T E M P_{i, y, m, j}$ represents

673 the number of days for which the daily maximum temperature was in each temperature bin $j$ (with each

674 month normalized to 30 days). We set $22-26^{\circ} \mathrm{C}$ as the base range. To focus on extremes, we initially

675 consider the daily maximum temperature. We then present estimates using the daily average temperature.

$676 Y_{i, y}$ is provincial per capita disposable income, and $\epsilon_{i, y, m}$ is an error term. $i, y$, and $m$ represent

677 province, year, and month. $\alpha_{j}$ is a vector of coefficients showing how monthly household electricity

678 consumption varies as a result of an additional day in each temperature bin. An additional day in each

679 bin will result in an increase in household electricity consumption of $100\left(\exp \left(\alpha_{j}\right)-1\right) \%$.

680 The specification controls for province fixed effects, $\gamma_{i}$, to capture time-invariant unobserved factors

\footnotetext{
${ }^{2}$ We assumed that the growth rate of per capita disposable income prior to 2013 equaled the growth rate of per capita rural net income.
} 
682 Geographical differences in electricity prices are partly captured by these province fixed effects ${ }^{3}$. Year

683 fixed effects, $\omega_{y}$, are included to control for common time-varying factors such as fluctuations in the

684 national economy. Month-of-year fixed effects, $\varphi_{m}$, are also controlled for to capture seasonal factors,

685 such as holidays, cultures, and customs. For example, Chinese weddings are usually held in May,

686 October, and December. Rural work schedules are also a function of the season.

687 The vector of control variables, $\vec{X}_{i, y}^{\prime}$, includes monthly average relative humidity, as relative humidity

688 is likely to be a key factor influencing the use of air conditioners (Garrido-Perez et al 2021). The annual

689 provincial urbanization rate is also included, as urbanization is closely linked to the penetration of air

690 conditioners (IEA 2018). Cities can also generally provide more effective adaptation options to extreme

691 temperatures, for example the ability to visit an air-conditioned mall (Bretschger and Pittel 2020). The

692 vector also includes a Spring Festival binary variable. Spring Festival is the most important festival on

693 the Chinese calendar, with large movements of people from urban to rural areas and from developed to

694 less developed ones. Spring Festival is in either January or February or can overlap the two (depending

695 on the year), so its effects are not fully picked up by the month-of-year fixed effects. ${ }^{4}$

\footnotetext{
${ }^{3}$ China implemented a step tariff for electricity since 2012, with three pricing steps established. The first step, covering around $80 \%$ of residents, has modest differences between provinces and has varied only slightly over time.

${ }^{4}$ We set the variable as 1 if Spring Festival is in a given month and 0 otherwise. If the festival overlaps months, we set the variable as 1 for the month covering the majority of the vacation. For jobholders, the duration of the vacation is generally around a week.
} 
699 effect of an extra day in a temperature bin over the current plus lagged month is $\alpha_{j}+\alpha_{1 j}$ :

$\ln E C_{i, y, m}=\sum_{j} \alpha_{j} T E M P_{i, y, m, j}+\sum_{j} \alpha_{1 j} T E M P_{i, y, m-1, j}+\beta \ln Y_{i, y}+\lambda \vec{X}_{i, y}^{\prime}+\gamma_{i}+\omega_{y}+\varphi_{m}$

To examine potential heterogeneity as a result of climatic and other differences, we explore the

703 importance of the north-south regional divide according to the Qinling-Huaihe Line. ${ }^{5}$ Specifically, we

704 interact north/south regional dummy variables with the temperature bin variables to obtain separate

705 estimates for the north and south:

$\ln E C_{i, y, m}=\sum_{j} \alpha_{j} T E M P_{i, y, m, j}+D_{i} \sum_{j} \alpha_{j} T E M P_{i, y, m, j}+\beta \ln Y_{i, y}+\lambda \vec{X}_{i, y}^{\prime}+\gamma_{i}+\omega_{y}+\varphi_{m}$

708 where $D_{i}=\left\{\begin{array}{l}0, \text { provinces located in the south } \\ 1, \text { provinces located in the north }\end{array}\right.$

709 We also estimate separate responses for urban and rural areas. To do so we use separate urban and rural

710 residential electricity consumption measures by province, while controlling for urban and rural measures

711 of per capita disposable income. We use the same temperature measures as in the main analysis.

\footnotetext{
5 The north includes Beijing, Tianjin, Hebei, Shanxi, Inner Mongolia, Liaoning, Jilin, Heilongjiang, Shandong, Henan, Shaanxi, Gansu, Qinghai, Ningxia, and Xinjiang. The south includes Jiangsu, Zhejiang, Anhui, Fujian, Jiangxi, Hubei, Hunan, Guangdong, Chongqing, Sichuan, Guizhou, and Yunnan.
} 
712 In robustness checks we control for interactions between the province and month-of-year fixed effects

713 so as to account for unobserved geographically-varying seasonal factors. We also control for month

714 fixed effects (i.e. year by month-of-year) to take common time-varying factors into account and explore

715 potential non-linear effects of per capita income by including a quadratic term. In addition we pursue

716 estimations using temperature bins based on the daily average rather than the daily maximum

717 temperature, with $14-18^{\circ} \mathrm{C}$ as the base group when doing so. Ten temperature bins are again used,

718 varying from above $30^{\circ} \mathrm{C}$ to below $-2^{\circ} \mathrm{C}$.

719 Temperatures are likely to be highly exogenous to any province's residential electricity use (Wang et al.

720 2008; Zivin and Neidell 2014; Levinson 2016). While greenhouse gas emissions from local electricity

721 generation will contribute to climate change (Hsiang and Kopp 2018), this is a global and gradually-

722 building effect rather than an immediate within-province feedback loop. China's emissions from

723 electricity and heat production for the residential sector also only accounted for $2.3 \%$ of the world's

724 carbon dioxide emissions from fuel combustion in 2017 (IEA 2019a). The link between household

725 electricity use and the urban heat island effect is also not expected to be strong, as urban heat effects

726 mainly relate to city size, urban surface geometry, and the radiative and thermal properties of physical

727 surfaces (Oke et al. 2017). Electricity is also typically generated outside cities. As a result, our

728 regressions should carry causal interpretations. The province fixed effects and various sets of time fixed

729 effects also help to control for key dimensions of unobserved variation that may be correlated with both

730 residential electricity use and temperatures. 


\subsection{Baseline results}

733 Table 1 shows the baseline results. Column (1) is an initial specification. Province fixed effects are

734 controlled for in column (2), year and month-of-year fixed effects in column (3), and the additional

735 variables in (4). The results are similar across the columns.

\section{Insert Table 1}

737 A key finding in Table 1 is that the response of household electricity to hot temperatures is larger than

738 the response to low temperatures. The likely reason is that cooling is currently more electricity-intensive

739 than heating in China. An additional day in the $>34^{\circ} \mathrm{C}$ maximum temperature range on average results

740 in around a $1.2-1.6 \%$ increase in monthly per capita household electricity consumption compared to if

741 that day had a maximum temperature in the range $22-26^{\circ} \mathrm{C}$. The effect for an additional day in the 30

$74234^{\circ} \mathrm{C}$ maximum temperature range is $1.1 \%$ (column (4)). For cold days, each additional day with a

743 maximum temperature of only $2-6^{\circ} \mathrm{C}$ on average leads to monthly per capita electricity consumption

744 increasing by only about $0.6 \%$ relative to if that day's maximum temperature had been in the base

745 category (column (4)). The hot and $2-6^{\circ} \mathrm{C}$ effects on residential electricity use are statistically different

746 from one another at the $1 \%$ significance level.

747 The estimates in Table 1 also indicate that residential electricity consumption is influenced by average

748 income levels. A $1 \%$ increase in average per capita disposable income on average leads to around a 0.6-

$749 \quad 1.5 \%$ increase in per capita household electricity consumption, depending on which control variables 
751 increase in the provincial urbanization rate on average leads to an increase in residential electricity

752 consumption of about $2.4 \%$.

753 Figure 4 displays the basic and distributed lag results in visual form. A U-shaped relationship between

754 household electricity consumption and the temperature bins is observable. For hot temperatures the two-

755 month response is larger than the one-month response, with each additional day with a maximum

756 temperature $>34^{\circ} \mathrm{C}$ leading to a $3.4 \%$ increase in the month's electricity consumption once the lagged

757 effect is included.

\section{Insert Fig. 4}

\subsection{Heterogeneity tests}

760 Figure 5 shows separate marginal effects for the south and north, obtained from a single estimation with

761 interaction terms. The lagged effects are not included. The results indicate that the proportional response

762 of residential electricity use to hot weather is larger in the north than the south (a difference that is

763 significant at the $1 \%$ level). This may be for two key reasons. First, households in the south are likely

764 to be more familiar with higher temperatures and tend to live in dwellings that are better equipped with

765 fittings such as external window shadings. ${ }^{6}$ Second, households in the south on average consume more

\footnotetext{
6 The average number of days for which the maximum temperature exceeds $34^{\circ} \mathrm{C}$ in southern provinces is around 22 per annum, five times the average for northern provinces.
} 
766

767 should be expected.

\section{Insert Fig.5}

769 The coefficient for the number of $<2^{\circ} \mathrm{C}$ days in the south is not significantly different from zero (Figure

770 5). It is also imprecisely estimated given that it is rare to have extremely cold weather in the south. For

771 the north, the effect for the $<2{ }^{\circ} \mathrm{C}$ temperature bin is significant at the $5 \%$ level and is slightly smaller

772 than that for the $2-6^{\circ} \mathrm{C}$ temperature bin. This is perhaps because some residents switch to using solid

773 fuels on extremely cold days.

774 Figure 6 shows separate response curves for urban and rural residents. For urban residents, the curve

775 rises steeply for days with a maximum temperature over $26^{\circ} \mathrm{C}$ as well as days below $10^{\circ} \mathrm{C}$. An additional

776 day $>34^{\circ} \mathrm{C}$ in a month tends to result in a $1.6 \%$ increase in monthly per capita electricity consumption

777 in urban areas, but in rural areas this figure is only 1.0\%. A probable contributor to this difference is

778 that there are fewer air conditioners in rural China. Each additional day per month with a maximum

779 temperature in the range $2-6^{\circ} \mathrm{C}$ tends to make urban monthly per capita electricity consumption increase

780 by about $0.9 \%$. The effect of days in this temperature bin is just $0.5 \%$ for rural residents.

\section{Insert Fig. 6}

782 For rural areas, the estimated effect for the $6-10^{\circ} \mathrm{C}$ temperature bin is larger than for the $<2^{\circ} \mathrm{C}$

\footnotetext{
7 Per capita annual electricity consumption in the south was around 27\% higher than the north in 2017.
} 
783

temperature bin, though the latter effect is not statistically significant. This is perhaps due to some dependence on electricity instead of coal for heating in the rural south, where maximum temperatures do not drop too low. Heating in the rural north remains dominated by solid fuels rather than electricity. Solid fuels exhibit low combustion efficiency and lead to serious air pollution problems (Chafe et al. 2014).

As shown in Table 2, electricity consumption appears to be quite insensitive to per capita income in urban areas, while in rural areas the income elasticity is above 3. It makes sense that residential electricity use is more closely tied to incomes. Rural residents remain at an earlier stage in the process of energy transition, with residents typically transitioning to cleaner energy sources such as electricity as their incomes rise (Barnes et al. 1997).

Insert Table 2

\subsection{Robustness checks}

Table 3 presents results for alternative specifications. Columns (7)-(8) control for the alternative sets of fixed effects: province by month-of-year fixed effects and month fixed effects, respectively. We take non-linear effects of income into consideration in column (9), observing an inverted U-shaped effect of per capita disposable income on per capita residential electricity consumption. The turning point is at around 83,000 yuan per capita (in year-2008 terms), which will be reached after 2050 according to the Economist Intelligence Unit (EIU). ${ }^{8}$

\footnotetext{
${ }^{8}$ See https://www.eiu.com.
} 
802 Column (10) of Table 3 uses temperature bins based on the daily average instead of the daily maximum

803 temperature. An additional day per month with an average temperature $>30^{\circ} \mathrm{C}$ on average results in a

$8042 \%$ increase in per capita electricity consumption in the month relative to the reference average

805 temperature of $14-18^{\circ} \mathrm{C}$. The trough-to-peak magnitude is slightly higher than when using the daily

806 maximum, perhaps because the daily average is more closely related to day-long electricity use needs.

807 Each additional day with a low average temperature on average leads to an increase of around $0.4-0.6 \%$

808 in monthly electricity use.

8094 Scenario: increase in residential electricity use induced by climate change

810 The IPCC $6^{\text {th }}$ Assessment Report (WG I Chapter 4; Lee et al 2021) provided scenarios for global average

811 surface air temperature in the long-term (2081-2100) under different greenhouse gas emission

812 trajectories. We consider three scenarios: SSP2-4.5, SSP3-7.0, and SSP5-8.5. These will see average

813 temperature increases of around $1.8^{\circ} \mathrm{C}, 2.8^{\circ} \mathrm{C}$, and $3.5^{\circ} \mathrm{C}$ by 2100 relative to $1995-2014$, respectively.

814 We make the assumption that the temperature increase in China accords with the global-average

815 temperature increase and that the temperature shifts up by the same amount throughout the day and year.

816 Based on our main estimates we then estimate the change in electricity consumption by 2100 attributed

817 solely to the rise in temperature under the three climate scenarios, using provincial population weights

818 in the aggregation process. The calculation is shown in equation (4), where $y 1, y 2$, and $m$ represent the

819 base year (2010), the final year, and each month, respectively. We use year-2010 population weights. 


$$
\text { effect } \%_{m}=\sum_{j} \alpha_{j}\left(T E M P_{j, m}^{y 2}-T E M P_{j, m}^{y 1}\right)
$$

821 The results are shown in Figure 7. Under all three scenarios, annual per capita household electricity

822 consumption in 2081-2100 is expected to be about 3-5\% higher in 2010 due to the expected temperature

823 rise alone. This is a small overall effect when considered against the large increase in residential

824 electricity use that is likely to result from future income growth and ongoing electrification of residential

825 energy services. The effect is highly seasonal. Under the SSP2-4.5 scenario, per capita household

826 electricity consumption in summer will increase by around $8 \%$ due to the warming effect. In winter,

827 electricity consumption will decrease by about $1 \%$ as heating needs decline. Under SSP5-8.5, residential

828 electricity use in China is expected to increase by $14 \%$ from June to August relative to 2010 levels.

829 Demand for residential electricity in spring and autumn would also increase.

\section{Insert Fig. 7}

\section{Comparisons to previous studies}

832 In order to compare our results with other research we refer to results using the daily average temperature.

833 Compared to $14-18^{\circ} \mathrm{C}$, an additional day per month in the $26-30^{\circ} \mathrm{C}$ or $>30^{\circ} \mathrm{C}$ average temperature bins

834 on average leads to monthly per capita electricity consumption increasing by $1.1 \%$ or $2.0 \%$, respectively.

835 This figure is approximately $0.6 \%$ and $0.4 \%$ for an extra day $<-2{ }^{\circ} \mathrm{C}$ or in the range -2 to $2{ }^{\circ} \mathrm{C}$.

836 We compare our results with the studies for the US of Deschenes and Greenstone (2011), Davis and

837 Gertler (2015), and Li et al. (2019). The temperature-electricity response function estimates in these

838 studies are also generally non-linear, with a larger increase in electricity consumption for hot days than 
840 Deschenes and Greenstone (2011) estimated the response function between the daily average

841 temperature and household energy consumption at the state level in the United States. They found a U-

842 shaped effect, consistent with our results for China. They found that each additional day with an average

843 temperature in the range $80-90^{\circ} \mathrm{F}$ (around $27-32^{\circ} \mathrm{C}$ ) and above $90^{\circ} \mathrm{F}$ (around $32^{\circ} \mathrm{C}$ ) will lead to a $0.2 \%$

844 and $0.4 \%$ increase in annual household energy consumption, respectively, compared to if that day's

845 average temperature had been in the range $50-60^{\circ} \mathrm{F}$ (around $10-16^{\circ} \mathrm{C}$ ).

846 Davis and Gertler (2015) used micro data from Mexico to estimate the relationship between temperature

847 and residential electricity consumption. They found that an additional day with an average temperature

848 in the range $85-90{ }^{\circ} \mathrm{F}$ (around $29-32^{\circ} \mathrm{C}$ ) or $90^{\circ} \mathrm{F}$ (around $32^{\circ} \mathrm{C}$ ) and above will increase monthly

849 electricity consumption by $2.2 \%$ and $3.2 \%$, respectively, relative to if that day's average temperature

850 was in the range $65-70^{\circ} \mathrm{F}$ (around $18-21^{\circ} \mathrm{C}$ ). The response curve estimated in their study is J-shaped,

851 which differs from our U-shaped response profile. However Mexico and China differ substantially in

852 their climates. The response curve is not well measured for low temperature ranges in Mexico given its

853 warm climate. Our results are otherwise quite similar to those for Mexico.

$854 \mathrm{Li}$ et al. (2019) used micro data on household electricity consumption in Shanghai to construct a

855 temperature-electricity response relationship. They found that an additional day with an average

856 temperature $>32^{\circ} \mathrm{C}$ per month would result in a $5.7 \%$ increase in the monthly household electricity

857 consumption, a larger effect than our results for urban areas. This is perhaps explained by the fact that 
858 Shanghai is one of the wealthiest cities in China, with a high penetration of air conditioners.

\section{Conclusions}

860 Understanding key responses to temperature extremes is important for modeling of the effects of climate

861 change (Tol and Yohe 2006), for electricity system planning, and for other purposes. In this study we

862 assembled a dataset of daily temperatures using an inverse distance weighting method and explored the

863 effect of daily temperatures on monthly household electricity consumption data in China. The paper

864 contributes to understanding the responses to climate change in a key country in the developing world.

865 We draw conclusions and implications as follows:

$866 \quad 6.1$ The response function is $U$ shaped, with heterogeneity by region

867 We found that the temperature response function for residential electricity use is U-shaped. Responses

868 to high temperatures are larger than responses to low temperatures, for the likely reason that residential

869 demand for air conditioning, electric fans, and refrigeration increases on hot days. Electricity is typically

870 less vital as an energy source on cold days, with biomass, coal, and natural gas all quite commonly being

871 used for space heating in China.

872 The electricity consumption of residents is less sensitive to high temperatures in southern provinces than

873 in the north (in proportional terms), likely because people and residences are more accustomed and

874 adapted to heat and because the underlying residential electricity usage level is higher in the south.

875 Urban residents are more likely to increase their electricity use in hot or cold weather than rural residents,

876 likely at least in part due to greater availability of air conditioners. There is still huge growth potential 
877 in both air-conditioner adoption and use in China, especially in rural areas.

\section{$878 \quad 6.2$ Effects of future warming}

879 Our estimates are useful for understanding the effects of future climate change on residential electricity

880 consumption in China. We estimate the effects by 2100 relative to 2010 under different carbon emission

881 scenarios based on the IPCC projections. As the climate warms, residents will face greater cooling needs

882 in summer and reduced heating needs in winter. Our estimates suggest that total residential electricity

883 consumption will likely increase by about $3-5 \%$, with an increase that could be as high as $14 \%$ in

884 summer months. Residential electricity demand in China tends to peak in summer, so additional pressure

885 on summer demand will add to China's investment needs in electricity generation, transmission, and

886 distribution.

887 One way to alleviate the emission pressures from rising summertime residential electricity demand is

888 increased use of rooftop solar photovoltaic (PV) and battery storage technologies. These distributed

889 technologies would also reduce the need for grid-level infrastructure investments. China accounted for

$89030 \%$ of solar PV electricity generation globally in 2017 (IEA 2019b), and there is substantial potential

891 for expansion in the country's rooftop solar PV market. As the cost of solar PV decreases, electricity

892 storage technologies improve, and household wealth accumulates, residents are more likely to install

893 solar panels (Best et al. 2019). Rural residents in China are advantaged in terms of greater physical

894 potential to install rooftop solar PV due to higher prevalence of private roofing. Urban residents are

895 more likely to live in apartment buildings. 
897 a key topic from a climate change adaptation point of view. It would also be of interest to explore the

898 effects of extreme temperature days - both hot and cold - on the use of other types of energy at the

899 residential level, such as coal and natural gas.

900 Declarations

901 Conflict of interest The authors declare no conflict of interest.

902 Ethics approval Not applicable.

903 Consent to participate Not applicable.

904 Consent for publication Not applicable.

905

906

\section{References}

907 Al-Bajjali SK, Shamayleh AY (2018) Estimating the determinants of electricity consumption in Jordan.

908 Energy 147: 1311-1320. https://doi.org/10.1016/j.energy.2018.01.010

909 Asadoorian MO, Eckaus RS, Schlosser CA (2008) Modeling climate feedbacks to electricity demand:

910 The case of China. Energy Econ 30(4): 1577-1602. https://doi.org/10.1016/j.eneco.2007.02.003

911 Auffhammer M, Aroonruengsawat A (2011) Simulating the impacts of climate change, prices and 912 population on California's residential electricity consumption. Clim Change 109(S1): 191-210.

913 https://doi.org/10.1007/s10584-011-0299-y

914 Auffhammer M (2014) Cooling China: The weather dependence of air conditioner adoption. Front Econ 915 China 9(1): 70-84. https://doi.org/10.3868/s060-003-014-0005-5

916 Auffhammer M, Mansur ET (2014) Measuring climatic impacts on energy consumption: A review of 917 the empirical literature. Energy Econ 46: 522-530. https://doi.org/10.1016/j.eneco.2014.04.017 
918 Barnes DF, Van der Plas R, Floor W (1997) Tackling the rural energy problem in developing countries.

919 Finance Dev June 1997. https://doi.org/10.5089/9781451952735.022

920 Barreca A, Clay K, Deschenes O, Greenstone M, Shapiro JS (2016) Adapting to climate change: The 921 remarkable decline in the US temperature-mortality relationship over the twentieth century. J Polit $922 \quad$ Econ 124: 105-159. https://doi.org/10.1086/684582

923 Baxter LW, Calandri K (1992) Global warming and electricity demand: A study of California. Energy 924 Policy 20(3): 233-244. https://doi.org/10.1016/0301-4215(92)90081-C

925 Berkouwer SB (2020) Electric heating and effects of temperature on household electricity consumption 926 in South Africa. Energy J 41(4): 1944-9089. https://doi.org/10.5547/01956574.41.4.sber

Best R, Burke PJ, Nishitateno S (2019) Understanding the determinants of rooftop solar installation:

Bessec M, Fouquau J (2008) The non-linear link between electricity consumption and temperature in Europe: A threshold panel approach. Energy Econ 30: 2705-2721. https://doi.org/10.1016/j.eneco.2008.02.003

Bretschger L, Pittel K (2020) Twenty key challenges in environmental and resource economics. Environ Evidence from household surveys in Australia. Aust J Agric Resour Econ 63: 922-939. https://doi.org/10.1111/1467-8489.12319

$$
\text { Resource Econ 77: 725-750. https://doi.org/10.1007/s10640-020-00516-y }
$$

Burke M, Craxton M, Kolstad CD et al (2016) Opportunities for advances in climate change economics. Science 352(6283): 292-293. https://doi.org/10.1126/science. aad9634

937 Burke PJ, Abayasekara A (2018) The price elasticity of electricity demand in the United States: A three938 dimensional analysis. Energy J 39(2): 123-146. https://doi.org/10.5547/01956574.39.2.pbur

939 Chafe ZA, Brauer M, Klimont Z et al (2014) Household cooking with solid fuels contributes to ambient 940 PM2.5 air pollution and the burden of disease. Environ Health Perspect (12): 1314-1320. 
942 Chen S, Oliva P, Zhang P (2017) The effect of air pollution on migration: Evidence from China. NBER

$943 \quad$ Working Paper No. 24036. https://doi.org/10.3386/w24036

944 CMA (China Meteorological Administration) (2021) Blue Book on Climate Change in China 2021.

945 Science Press, Beijing.

946

947

948

949

950

951

952

953

954

955

956

Davis LW, Gertlera PJ (2015) Contribution of air conditioning adoption to future energy use under global warming. Proc Natl Acad Sci USA 112 (19): 5962-5967. https://doi.org/10.1073/pnas.1423558112

Dell M, Jones BF, Olken BA (2014) What do we learn from the weather? The new climate-economy literature. J Econ Lit 52: 740-798. https://doi.org/10.1257/jel.52.3.740

Deschenes O, Greenstone M (2011) Climate change, mortality, and adaptation: Evidence from annual fluctuations in weather in the US. Am Econ J-Appl Econ 3: 152-185. https://doi.org/10.1257/app.3.4.152

Ebenstein A, Fan MY, Greenstone M, He GJ, Zhou MG (2017) New evidence on the impact of sustained exposure to air pollution on life expectancy from China's Huai River Policy. Proc Natl Acad Sci USA 114(39): 10384. https://doi.org/10.1073/pnas.1616784114

Eom J, Hyun M, Lee J, Lee H (2020) Increase in household energy consumption due to ambient air pollution. Nat Energy 5: 976-984. https://doi.org/10.1038/s41560-020-00698-1

Fan J, Tang B, Hao Y (2015) Impact of climatic factors on monthly electricity consumption of China's sectors. Nat Hazards 75: 2027-2037. https://doi.org/10.1007/s11069-014-1375-1

Fonseca FR, Jaramillo P, Bergés M, Severnini E (2019). Seasonal effects of climate change on intra-day electricity demand patterns. Clim Change 154: 435-451. https://doi.org/10.1007/s10584-019-02413W 
964 Franco G, Sanstad AH (2008) Climate change and electricity demand in California. Clim Change 87:

965 139-151. https://doi.org/10.1007/s10584-007-9364-y

966 Garrido-Perez JM, Barriopedro D, García-Herrera R, Ordóñez C (2021) Impact of climate change on

967 Spanish electricity demand. Clim Change 165: 50. https://doi.org/10.1007/s10584-021-03086-0

968 Ghimire YN, Shivakoti GP, Perret SR (2010) Household-level vulnerability to drought in hill agriculture

969 of Nepal: Implications for adaptation planning. Int J Sustain Dev World Ecol 17(3): 225-230.

$970 \quad$ https://doi.org/10.1080/13504501003737500

971 Hsiang S, Kopp RE (2018) An economist's guide to climate change science. J Econ Perspect 32(4): 3-

972 32. https://doi.org/10.1257/jep.32.4.3

973 IEA (2018) The future of cooling. International Energy Agency, Paris

974 IEA (2019a) $\mathrm{CO}_{2}$ emissions from fuel combustion. International Energy Agency, Paris

975 IEA (2019b) Renewables information 2019. International Energy Agency, Paris

976 Lam JC (1998) Climatic and economic influences on residential electricity consumption. Energy Conv

977 Manag 39(7): 623-629. https://doi.org/10.1016/S0196-8904(97)10008-5

978 Lee JY, Marotzke J, Bala G et al (2021) Future global climate: Scenario-based projections and near-

979 term information. In: Climate change 2021: The physical science basis. Contribution of Working

980 Group I to the Sixth Assessment Report of the Intergovernmental Panel on Climate Change [Masson-

981 Delmotte V, Zhai P, Pirani A et al (eds.)]. Cambridge University Press. In Press.

982 Levinson A (2016) How much energy do building energy codes save? Evidence from California houses.

983 Am Econ Rev 106(10): 2867-94. https://doi.org/10.1257/aer.20150102

984 Li Y, Pizer WA, Wu L (2019) Climate change and residential electricity consumption in the Yangtze

985 River Delta, China. Proc Natl Acad Sci USA 116(2): 472-477. https://doi.org/

$986 \quad 10.1073 /$ pnas. 1804667115 
1002

Mansur ET, Mendelsohn R, Morrison W (2008) Climate change adaptation: A study of fuel choice and consumption in the U.S. energy sector. J Environ Econ Manage 55(2): 175-193. https://doi.org/10.1016/j.jeem.2007.10.001

McCulloch J, Ignatieva K (2020) Intra-day electricity demand and temperature. Energy J 41(3): 161181. https://doi.org/10.5547/01956574.41.3.jmcc

NBS (National Bureau of Statistics) (2019a) China Energy Statistical Yearbook 2018. China Statistical Press, Beijing

NBS (National Bureau of Statistics) (2019b) China Statistical Yearbook 2018. China Statistical Press, Beijing

NEA (National Energy Administration) (2007) Ten major events of China's energy development in 2006. http://www.nea.gov.cn/2007-01/18/c_131058342.htm

Oke TR, Mills G, Christen A, Voogt JA (2017) Urban climates. Cambridge University Press, Cambridge.

Park J, Goodman J, Hurwitz M, Smith J (2020) Heat and learning. Am Econ J-Econ Polic 12(2): 306339. https://doi.org/10.1257/pol.20180612

Revesz R, Howard P, Arrow K et al. (2014) Global warming: Improve economic models of climate change. Nature 508: 173-175. https://doi.org/10.1038/508173a

Tjørring L, Jensen CL, Hansen LG, Andersen LM (2018) Increasing the flexibility of electricity consumption in private households: Does gender matter? Energy Policy 118: 9-18. https://doi.org/10.1016/j.enpol.2018.03.006

Tol RSJ, Yohe G (2009) The Stern Review: A deconstruction. Energy Policy 37: 1032-1040. https://doi.org/10.1016/j.enpol.2008.11.008

Vine E (2012) Adaptation of California's electricity sector to climate change. Clim Change 111: 75-99. https://doi.org/10.1007/s10584-011-0242-2 
1010 Wang J, Mendelsohn R, Dinar A, Huang J, Rozelle S (2008) Can China continue feeding itself? The 1011 impact of climate change on agriculture. Policy Research Working Paper. https://doi.org/ $1012 \quad 10.1596 / 1813-9450-4470$

1013 Wang Z, Sun Y, Wang B (2020) Policy cognition is more effective than step tariff in promoting 1014 electricity saving behaviour of residents. Energy Policy 139: 111338. 1015 https://doi.org/10.1016/j.enpol.2020.111338

1016 Warren HE, LeDuc SK (1981) Impact of climate on energy sector in economic analysis. J Appl Meteorol 1017 20: 1431-1439. https://doi.org/10.1175/15200450(1981)020<1431:IOCOES >2.0.CO;2

1018 WMO (2021) State of the global climate in 2020. World Meteorological Organization, Geneva. 1019 https://library.wmo.int/vig_num_norights.php?explnum_id=10618

1020 Wolfram C, Shelef O, Gertler P (2012) How will energy demand develop in the developing world? J 1021 Econ Perspect 26 (1): 119-138. https://doi.org/10.1257/jep.26.1.119

1022 Yohe G, Tol R (2002) Indicators for social and economic coping capacity: Moving toward a working 1023 definition of adaptive capacity. Global Environmental Change 12: 25-40. 1024 https://doi.org/10.1016/S0959-3780(01)00026-7

1025 Zhang C, Liao H, Mi Z (2019) Climate impacts: Temperature and electricity consumption. Nat Hazards 1026 99: 1259-1275. https://doi.org/10.1007/s11069-019-03653-w

1027 Zhou S, Teng F (2013) Estimation of urban residential electricity demand in China using household 1028 survey data. Energy Policy 61: 394-402. https://doi.org/10.1016/j.enpol.2013.06.092

1029 Zivin JG, Neidell MJ (2014) Temperature and the allocation of time: Implications for climate change. J 1030 Labor Econ 32(1): 1-26. https://doi.org/10.1086/671766

1031

1032 


\section{Tables}

1034

Table 1 Main results

Mode

(1)

(2)

(3)

(4)

Ln mean daily-average per capita household electricity consumption

\begin{tabular}{|c|c|c|c|c|}
\hline \multicolumn{5}{|l|}{ Number of days in month: } \\
\hline \multirow[t]{2}{*}{$>34^{\circ} \mathrm{C}$} & $0.012 * * *$ & $0.012 * * *$ & $0.016 * * *$ & $0.016 * * *$ \\
\hline & $(0.001)$ & $(0.001)$ & $(0.002)$ & $(0.002)$ \\
\hline \multirow[t]{2}{*}{$30-34^{\circ} \mathrm{C}$} & $0.008 * * *$ & $0.008 * * *$ & $0.011 * * *$ & $0.011 * * *$ \\
\hline & $(0.002)$ & $(0.002)$ & $(0.002)$ & $(0.002)$ \\
\hline \multirow[t]{2}{*}{$26-30^{\circ} \mathrm{C}$} & 0.000 & 0.000 & $0.003 * * *$ & $0.003 * * *$ \\
\hline & $(0.001)$ & $(0.001)$ & $(0.001)$ & $(0.001)$ \\
\hline \multirow[t]{2}{*}{$18-22^{\circ} \mathrm{C}$} & $0.002 *$ & $0.002 *$ & 0.001 & $0.002 * *$ \\
\hline & $(0.001)$ & $(0.001)$ & $(0.001)$ & $(0.001)$ \\
\hline \multirow[t]{2}{*}{$14-18^{\circ} \mathrm{C}$} & 0.000 & 0.000 & -0.000 & -0.000 \\
\hline & $(0.001)$ & $(0.001)$ & $(0.001)$ & $(0.001)$ \\
\hline \multirow[t]{2}{*}{$10-14^{\circ} \mathrm{C}$} & $0.002 *$ & 0.002 & 0.002 & 0.002 \\
\hline & $(0.001)$ & $(0.001)$ & $(0.001)$ & $(0.001)$ \\
\hline \multirow[t]{2}{*}{$6-10^{\circ} \mathrm{C}$} & $0.007 * * *$ & $0.008 * * *$ & $0.005^{* * *}$ & $0.005 * * *$ \\
\hline & $(0.001)$ & $(0.001)$ & $(0.001)$ & $(0.001)$ \\
\hline \multirow[t]{2}{*}{$2-6^{\circ} \mathrm{C}$} & $0.007 * * *$ & $0.007 * * *$ & $0.006^{* * *}$ & $0.006^{* * *}$ \\
\hline & $(0.002)$ & $(0.002)$ & $(0.002)$ & $(0.002)$ \\
\hline \multirow[t]{2}{*}{$<2^{\circ} \mathrm{C}$} & $0.004 * * *$ & $0.005 * * *$ & 0.003 & 0.003 \\
\hline & $(0.001)$ & $(0.001)$ & $(0.002)$ & $(0.002)$ \\
\hline \multirow[t]{2}{*}{ Ln income per capita } & $0.861 * * *$ & $0.866^{* * *}$ & $1.461 * * *$ & 0.594 \\
\hline & $(0.046)$ & $(0.048)$ & $(0.411)$ & $(0.429)$ \\
\hline \multirow[t]{2}{*}{ Average humidity } & & & & -0.000 \\
\hline & & & & $(0.001)$ \\
\hline \multirow[t]{2}{*}{ Urbanization rate $(\%)$} & & & & $0.024 * * *$ \\
\hline & & & & $(0.007)$ \\
\hline \multirow[t]{2}{*}{ Spring festival (Binary) } & & & & $-0.071 * * *$ \\
\hline & & & & $(0.009)$ \\
\hline Province fixed effects & No & Yes & Yes & Yes \\
\hline Year fixed effects & No & No & Yes & Yes \\
\hline Month-of-year fixed effects & No & No & Yes & Yes \\
\hline Provinces & 30 & 30 & 30 & 30 \\
\hline Observations & 3,600 & 3,600 & 3,600 & 3,600 \\
\hline
\end{tabular}

1035 Note: The base temperature bin is $22-26^{\circ} \mathrm{C}$. Temperature refers to the daily maximum. Robust standard errors are in

1036 parentheses. *** Statistical significance at 1\%.** Statistical significance at 5\%. * Statistical significance at $10 \%$.

1037 
Table 2 Responses to temperature in urban and rural areas

\begin{tabular}{|c|c|c|}
\hline \multirow[t]{2}{*}{ Model } & (5) & (6) \\
\hline & Ln urban electricity consumption & Ln rural electricity consumption \\
\hline \multicolumn{3}{|l|}{ Number of days in month: } \\
\hline \multirow[t]{2}{*}{$>34^{\circ} \mathrm{C}$} & $0.016 * * *$ & $0.010 * * *$ \\
\hline & $(0.003)$ & $(0.003)$ \\
\hline \multirow[t]{2}{*}{$30-34^{\circ} \mathrm{C}$} & $0.013 * * *$ & $0.009 * * *$ \\
\hline & $(0.002)$ & $(0.002)$ \\
\hline \multirow[t]{2}{*}{$26-30^{\circ} \mathrm{C}$} & 0.002 & 0.002 \\
\hline & $(0.002)$ & $(0.001)$ \\
\hline \multirow[t]{2}{*}{$18-22^{\circ} \mathrm{C}$} & 0.002 & 0.001 \\
\hline & $(0.002)$ & $(0.001)$ \\
\hline \multirow[t]{2}{*}{$14-18^{\circ} \mathrm{C}$} & -0.001 & 0.001 \\
\hline & $(0.001)$ & $(0.001)$ \\
\hline \multirow[t]{2}{*}{$10-14^{\circ} \mathrm{C}$} & 0.001 & -0.001 \\
\hline & $(0.002)$ & $(0.002)$ \\
\hline \multirow[t]{2}{*}{$6-10^{\circ} \mathrm{C}$} & $0.007 * * *$ & $0.007 *$ \\
\hline & $(0.002)$ & $(0.003)$ \\
\hline \multirow[t]{2}{*}{$2-6^{\circ} \mathrm{C}$} & $0.009 * * *$ & $0.005^{*}$ \\
\hline & $(0.003)$ & $(0.003)$ \\
\hline \multirow[t]{2}{*}{$<2^{\circ} \mathrm{C}$} & 0.004 & 0.001 \\
\hline & $(0.003)$ & $(0.002)$ \\
\hline \multirow[t]{2}{*}{ Ln urban income per capita } & 0.030 & \\
\hline & $(0.235)$ & \\
\hline \multirow[t]{2}{*}{ Ln rural income per capita } & & $3.498 * * *$ \\
\hline & & $(0.766)$ \\
\hline Control variables & Yes & Yes \\
\hline Province fixed effects & Yes & Yes \\
\hline Year fixed effects & Yes & Yes \\
\hline Month-of-year fixed effects & Yes & Yes \\
\hline Provinces & 30 & 30 \\
\hline Observations & 2158 & 2159 \\
\hline
\end{tabular}

1039 Note: We show regression results for both urban and rural areas, comparing to $22-26^{\circ} \mathrm{C}$, with robust standard errors in

1040 parentheses. Data are for 2012 - 2017. The dependent variables use mean daily-average per capita data. *** Statistical

1041 significance at $1 \%$. ** Statistical significance at 5\%. * Statistical significance at $10 \%$. 
Table 3 Robustness checks

(4)

(7)

(8)

(9)

(10)

Ln mean daily-average per capita household electricity consumption

\begin{tabular}{|c|c|c|c|c|c|}
\hline \multicolumn{6}{|l|}{ Number of days in month: } \\
\hline \multirow[t]{2}{*}{$>34^{\circ} \mathrm{C}$} & $0.016^{* * *}$ & $0.013 * * *$ & $0.013 * * *$ & $0.014 * * *$ & \\
\hline & $(0.002)$ & $(0.002)$ & $(0.002)$ & $(0.002)$ & \\
\hline \multirow[t]{2}{*}{$30-34^{\circ} \mathrm{C}$} & $0.011 * * *$ & $0.007 * * *$ & $0.006^{* * *}$ & $0.006 * * *$ & \\
\hline & $(0.002)$ & $(0.001)$ & $(0.001)$ & $(0.001)$ & \\
\hline \multirow[t]{2}{*}{$>30^{\circ} \mathrm{C}$} & & & & & $0.020 * * *$ \\
\hline & & & & & $(0.003)$ \\
\hline \multirow[t]{2}{*}{$26-30^{\circ} \mathrm{C}$} & $0.003 * * *$ & 0.001 & 0.001 & 0.001 & $0.011 * * *$ \\
\hline & $(0.001)$ & $(0.001)$ & $(0.001)$ & $(0.001)$ & $(0.002)$ \\
\hline \multirow[t]{2}{*}{$22-26^{\circ} \mathrm{C}$} & & & & & $0.004^{* *}$ \\
\hline & & & & & $(0.001)$ \\
\hline \multirow[t]{2}{*}{$18-22^{\circ} \mathrm{C}$} & $0.002 * *$ & $0.002 *$ & $0.002 *$ & 0.002 & 0.000 \\
\hline & $(0.001)$ & $(0.001)$ & $(0.001)$ & $(0.001)$ & $(0.001)$ \\
\hline \multirow[t]{2}{*}{$14-18^{\circ} \mathrm{C}$} & -0.000 & 0.001 & 0.002 & 0.002 & \\
\hline & $(0.001)$ & $(0.001)$ & $(0.002)$ & $(0.002)$ & \\
\hline \multirow[t]{2}{*}{$10-14^{\circ} \mathrm{C}$} & 0.002 & 0.002 & 0.002 & 0.002 & $0.002 *$ \\
\hline & $(0.001)$ & $(0.002)$ & $(0.002)$ & $(0.002)$ & $(0.001)$ \\
\hline \multirow[t]{2}{*}{$6-10^{\circ} \mathrm{C}$} & $0.005^{* * *}$ & $0.003 * *$ & $0.004 * *$ & $0.004 * *$ & $0.002 *$ \\
\hline & $(0.001)$ & $(0.002)$ & $(0.002)$ & $(0.002)$ & $(0.001)$ \\
\hline \multirow[t]{2}{*}{$2-6^{\circ} \mathrm{C}$} & $0.006^{* * *}$ & 0.003 & 0.003 & 0.003 & $0.004 * *$ \\
\hline & $(0.002)$ & $(0.002)$ & $(0.002)$ & $(0.002)$ & $(0.002)$ \\
\hline \multirow[t]{2}{*}{$<2^{\circ} \mathrm{C}$} & 0.003 & $0.003 *$ & $0.005^{* *}$ & $0.005^{*}$ & \\
\hline & $(0.002)$ & $(0.002)$ & $(0.003)$ & $(0.003)$ & \\
\hline \multirow[t]{2}{*}{$-2-2^{\circ} \mathrm{C}$} & & & & & $0.004 * *$ \\
\hline & & & & & $(0.002)$ \\
\hline \multirow[t]{2}{*}{$<-2^{\circ} \mathrm{C}$} & & & & & $0.006^{* *}$ \\
\hline & & & & & $(0.003)$ \\
\hline \multirow[t]{2}{*}{ Ln income per capita } & 0.594 & $0.620 * * *$ & $0.622 * * *$ & $2.038 * * *$ & $0.629 * * *$ \\
\hline & $(0.429)$ & $(0.107)$ & $(0.108)$ & $(0.284)$ & $(0.108)$ \\
\hline \multirow[t]{2}{*}{$(\text { Ln income per capita })^{2}$} & & & & $-0.090 * * *$ & \\
\hline & & & & $(0.017)$ & \\
\hline $\begin{array}{l}\text { Province by month-of-year fixed } \\
\text { effects }\end{array}$ & No & Yes & Yes & Yes & Yes \\
\hline Month fixed effects & No & No & Yes & Yes & Yes \\
\hline
\end{tabular}

1043 Note: Columns (4) and (7)-(9) use the daily maximum temperature, with $22-26^{\circ} \mathrm{C}$ set as the baseline group. Column (10)

1044 uses the daily average temperature, with $14-18^{\circ} \mathrm{C}$ as the baseline group. Province, year, and month-of-year fixed effects and 
1045 the control variables are controlled for in all columns. Robust standard errors are in parentheses. *** Statistical significance at

$10461 \%$.** Statistical significance at 5\% * Statistical significance at 10\%. Each column covers 30 provinces and 3,600

1047 observations.

1048

Figures

1049

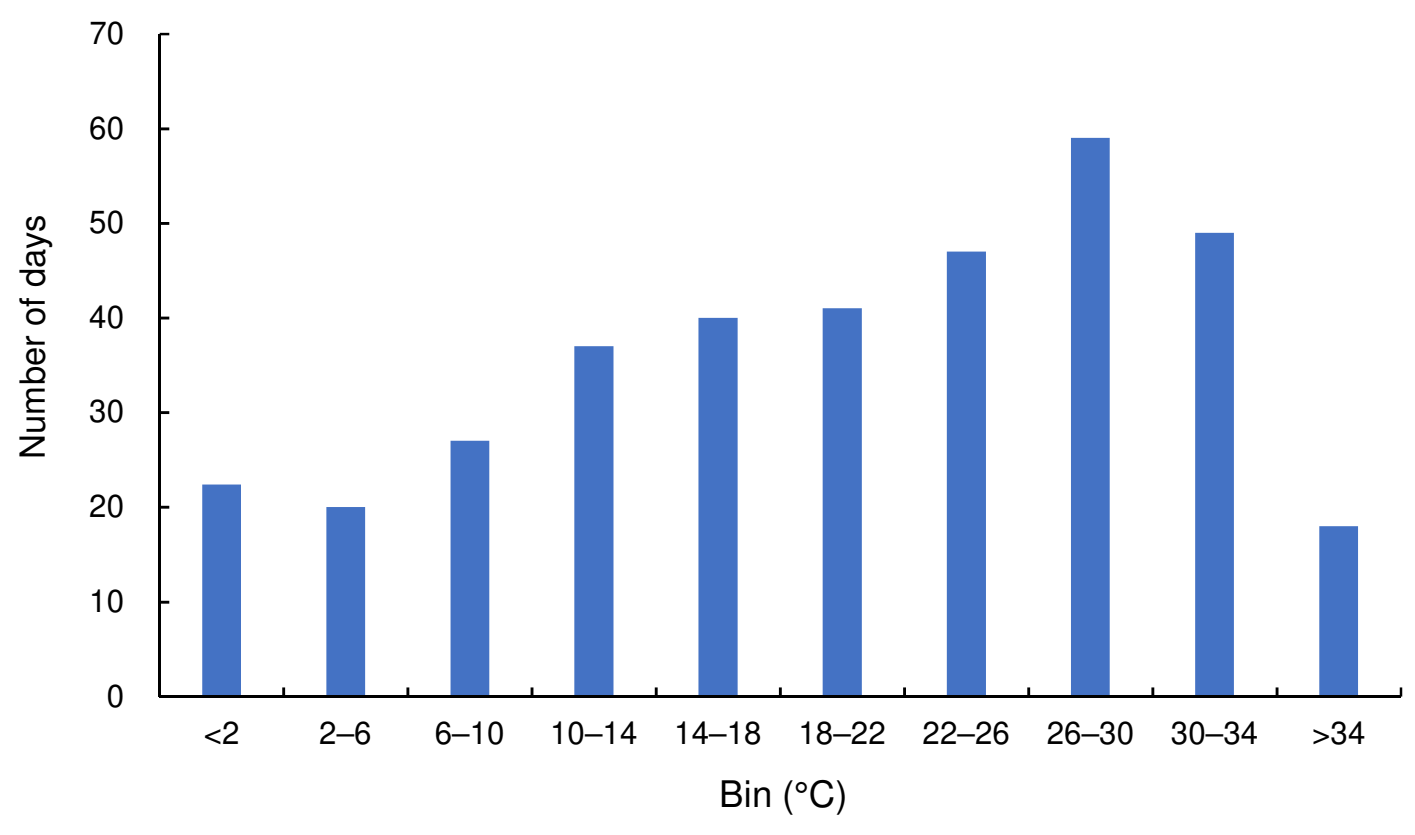

1050

1051

Fig. 1 Daily maximum temperature in 2017 (average for provinces)

1052 Note: All months are normalized to 30 days.

1053 
1054

1055

1056

1057

1058

1059

1060

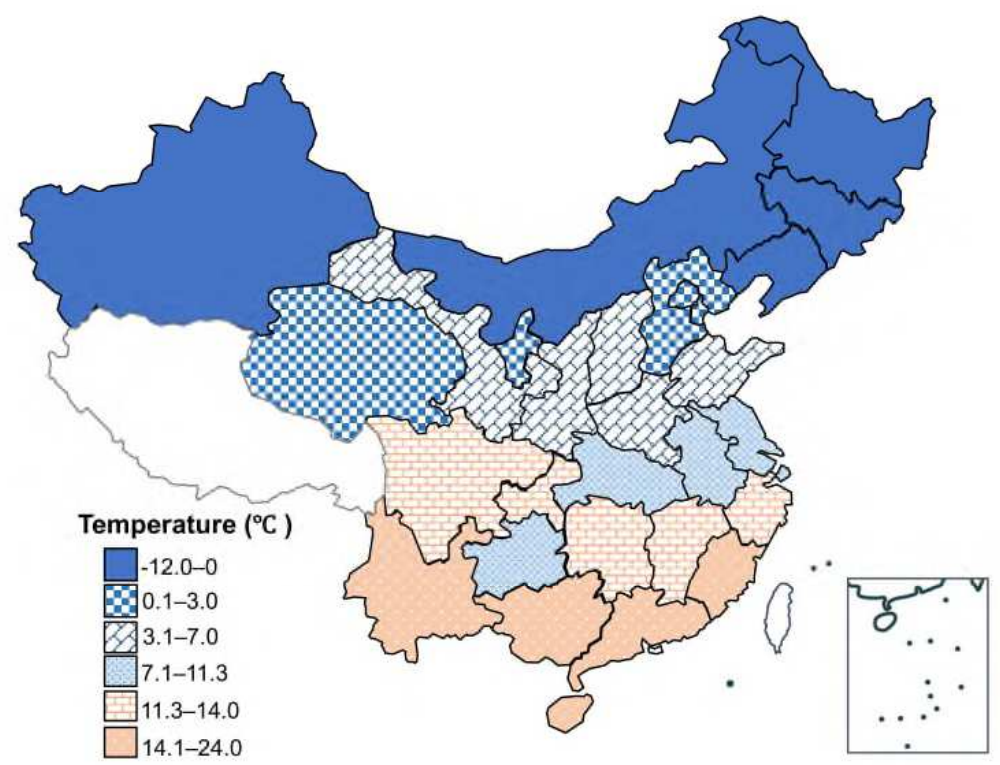

(a) January

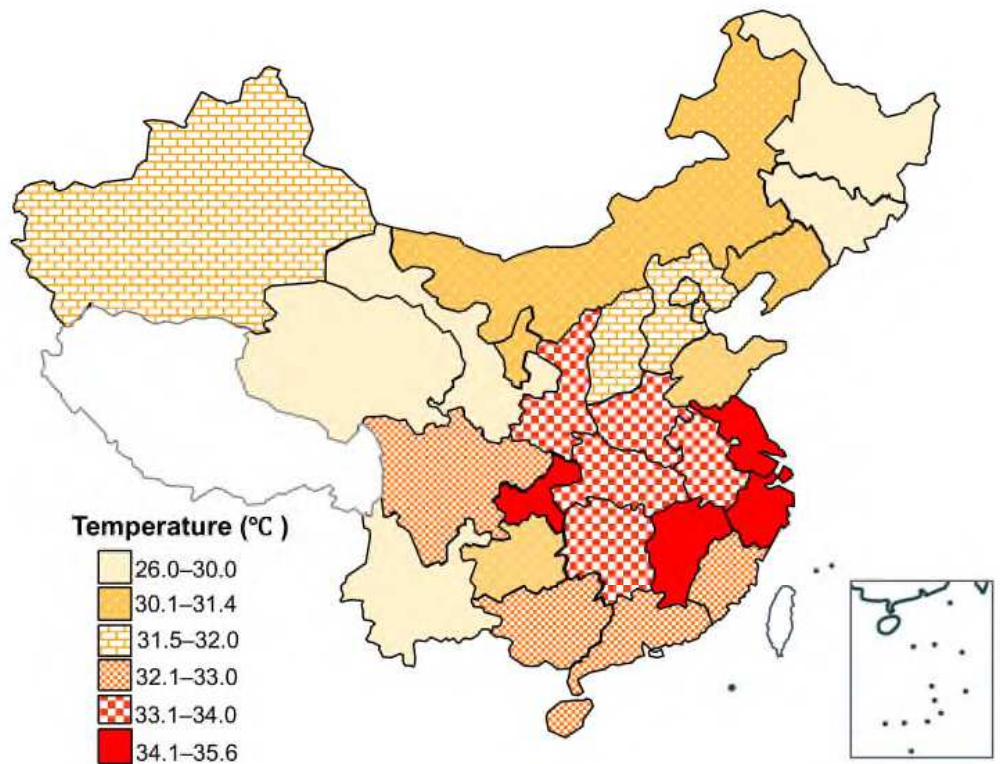

(b) July

Fig. 2 Average daily maximum temperature in January and July 2017

Note: Figure 2 shows the average daily maximum temperature at the province level in January (a) and July (b) of 2017.

Four provincial regions of China (Tibet, Hong Kong, Macau, and Taiwan) are not included in the econometric analysis 


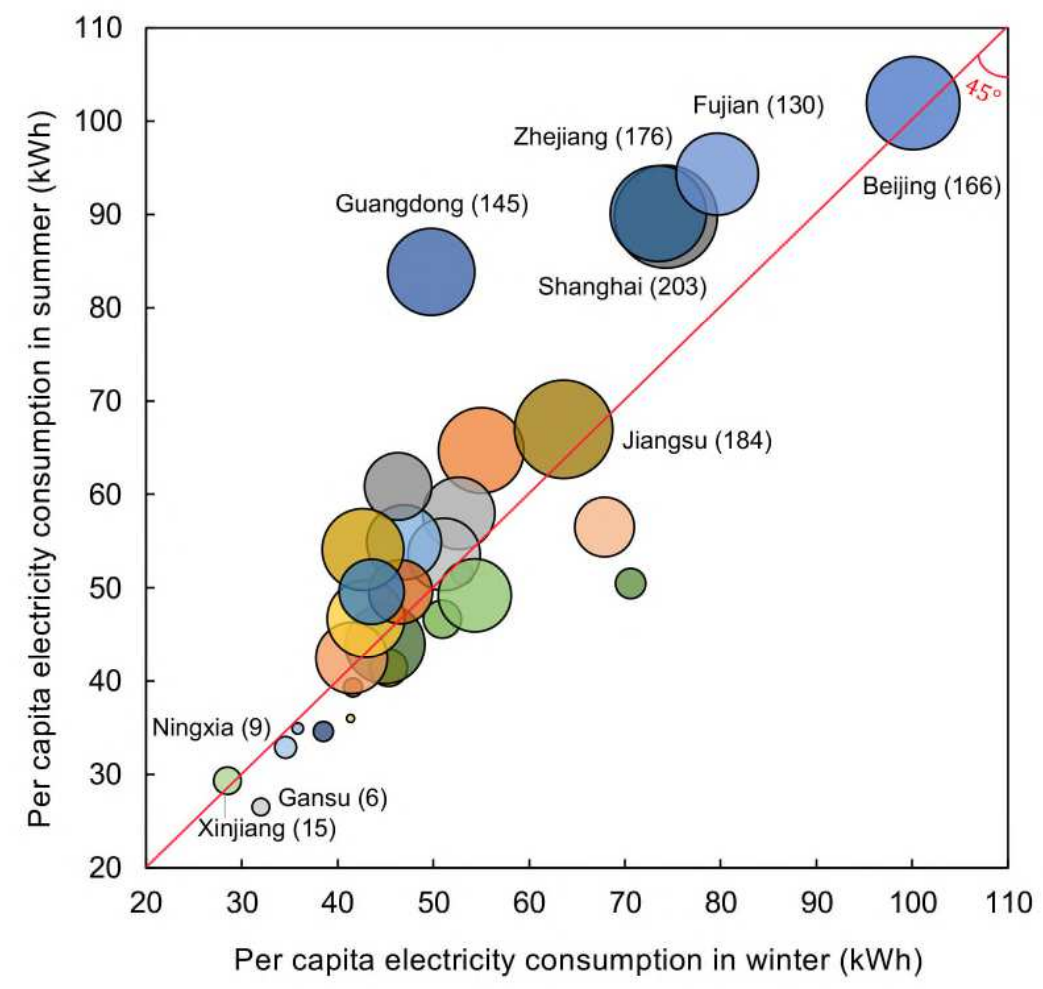

1064 Fig. 3 Per capita residential electricity consumption and the residential air conditioner stock by province, 2017

1066 Note: Shows provincial per capita residential electricity consumption in summer (June-August) and winter months

1067 (January, February, December) of 2017. The bubble size represents the number of residential air conditioners per 100

1068 households in 2017, derived from the China Statistical Yearbook. For selected provinces, the number is shown in 1069 parentheses.

1070 


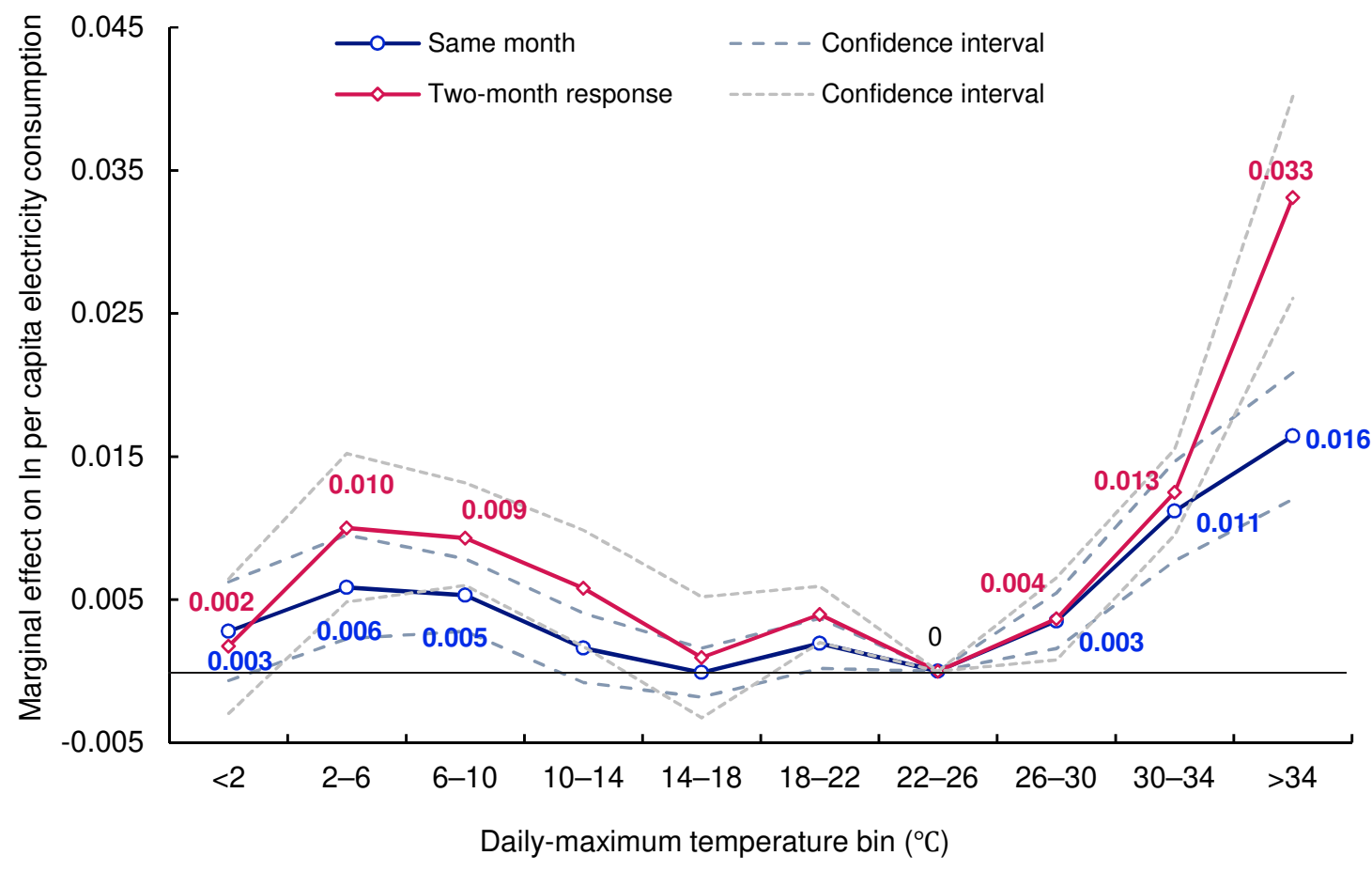

1072

Fig. 4 Same-month and two-month response functions

1073 Note: Shows the overall marginal effects from the basic model and the total effects from a model with one-month lagged

1074 temperature bin variables. Province, year, and month-of-year fixed effects and the control variables are controlled for.

$107595 \%$ confidence intervals are shown.

1076 


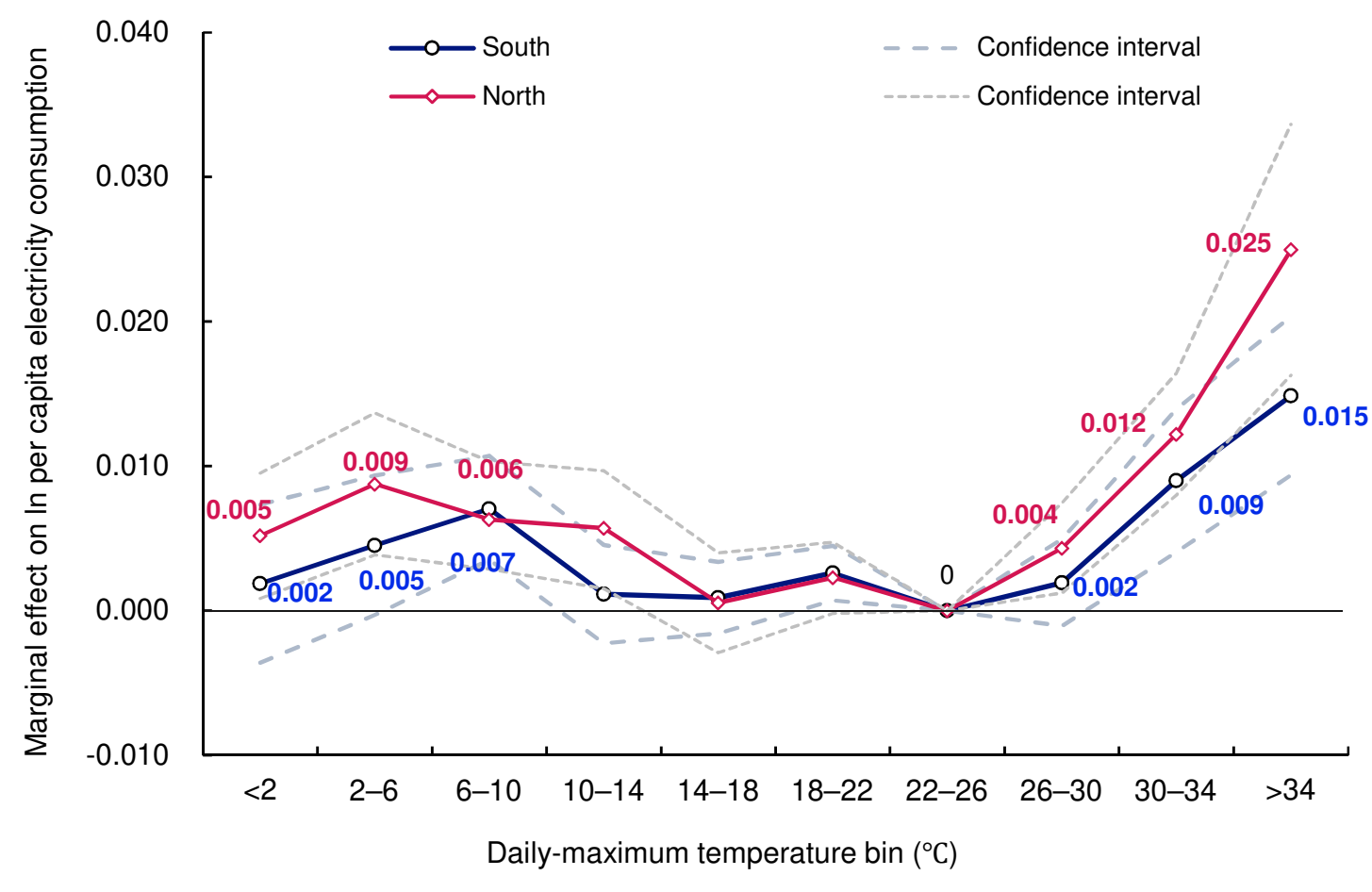

1078 Fig. 5 The response function in the south and the north

1079 Note: Regression results by region, with province, year, and month-of-year fixed effects and control variables considered.

1080 The solid line is the regression coefficient. The dashed lines show the 95\% confidence interval.

1081 


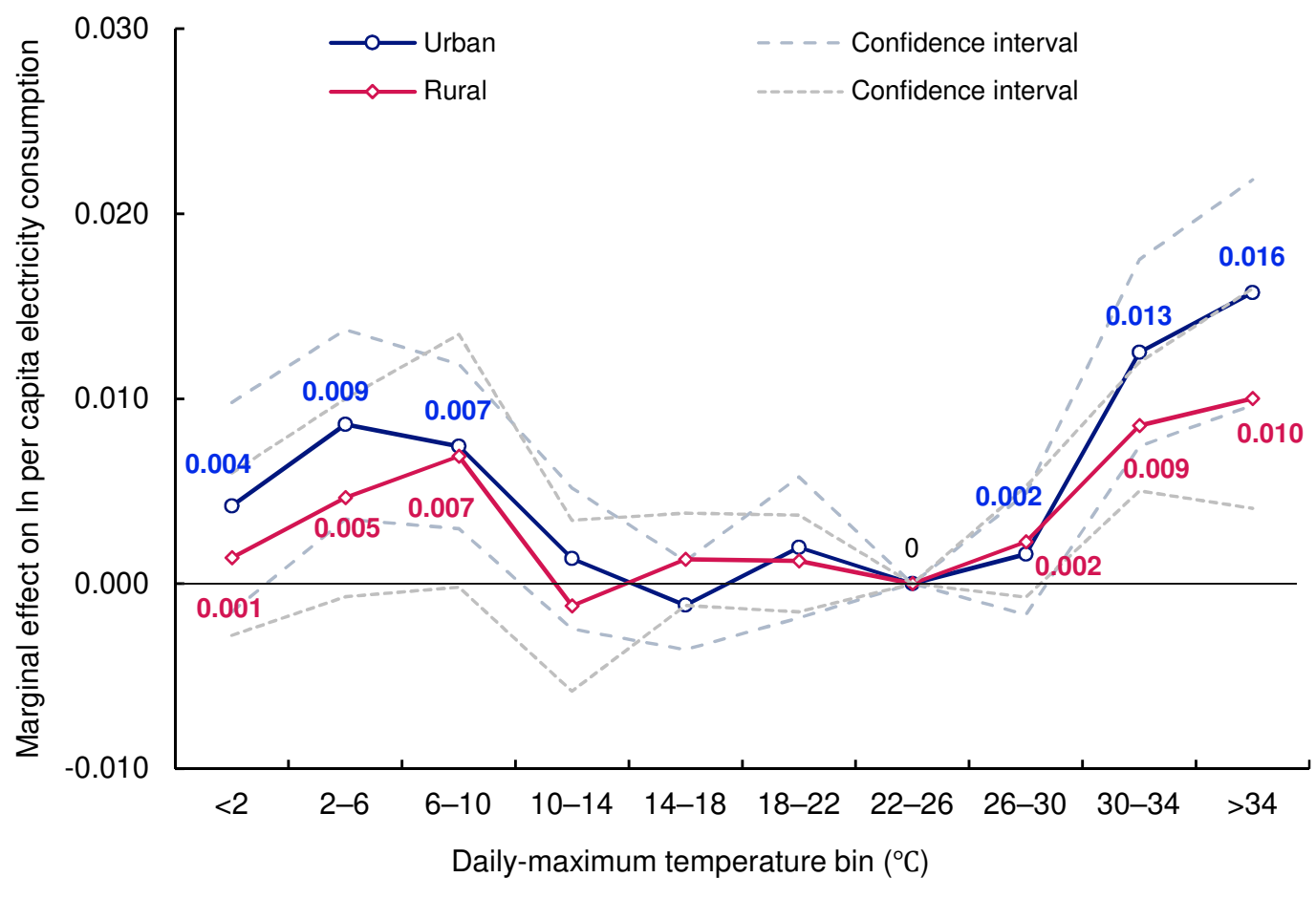

1083

Fig. 6 The response function in urban and rural areas

1084 Note: Shows separate regression results for urban and rural areas for 2012-2017. Province, year, and month-of-year fixed

1085 effects and the control variables are controlled for. The solid line is the regression coefficient. The dashed lines show the

$108695 \%$ confidence interval. The regression results are shown in Table 2.

1087 


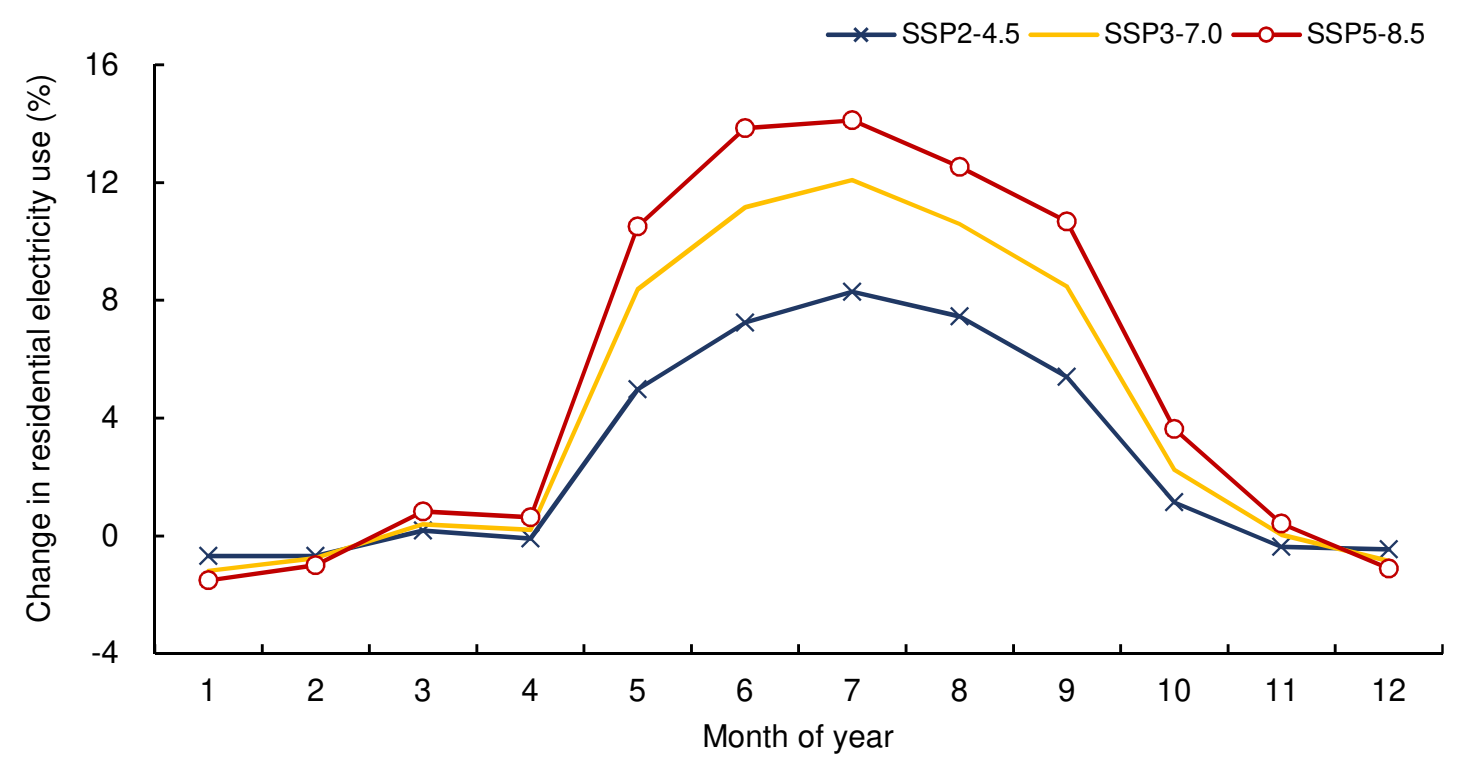

1088

Fig. 7 Monthly electricity consumption change under different climate scenarios

Note: We estimate the change in household electricity consumption attributed to expected temperature increases over

2010 - 2100 under three climate change scenarios. The estimation applies the estimates in our basic model for the 